\title{
Determinants of Willingness to Pay for Solid Waste Management in Gweru City, Zimbabwe
}

\author{
Zimbabwe, Gweru Şehrinde Katı Atık Yönetimi için Ödeme Yapma Iradesinin Belirleyicileri
}

\section{Mukarati Julius}

Department of Agricultural Economics and Development, Midlands State University (jmukarati@ gmail.com)

\author{
Nyamutowa Charles \\ Department of Agricultural Economics and Development, Midlands State University
}

\author{
Mufandaedza Shylet \\ Department of Economics, Great Zimbabwe University
}

\begin{abstract}
Keywords:

Waste

Management

Willingness to Pay

Contingent

Valuation Method

Municipalities

Many policies and frameworks in developing countries are directed at waste management. With increased rural to urban migration, most municipalities are faced with increased improper disposal of solid waste and one of the major constraints is limited financial capacity of local municipalities. The increasing financial challenges for waste management have prompted researchers to pay close attention to the demand side of the problem. This study seeks to analyse the determinants of household willingness to pay for improved residential solid waste management in Gweru. An open ended contingent valuation method was used to elicit household's willingness to pay and a binary logit model was used to account for the factors influencing the respondent's Willingness to Pay. The results from the study indicated that monthly average expenditure which is a proxy of household income, highest level of education and the age of household head are important determinants of household willingness to pay for solid waste management. The other variables were not statistically and significantly associated with the willingness to pay for waste management. The findings from this study indicate there is greater chance of success in solid waste management if there is the possibility of cost sharing.
\end{abstract}

\section{ÖZET}

Gelişmekte olan ülkelerdeki pek çok politika ve çerçeve atık yönetimine yöneliktir.Kırsaldan kente göçe arttıkça, çoğu belediye artan katı atıkların arıtılması ile karşı karşıyadır ve en büyük kısıtlamalardan birisi, yerel belediyelerin sinırlı mali kapasitesidir.Atık yönetimi için artmakta olan mali zorluklar, araştırmacıların sorunun talep tarafina yakından dikkat etmelerini sağlamıştır.Bu çalışma, Gweru'da konut katı atık yönetiminin iyileştirilmesi için hanehalkı gönüllü olma istekliliğinin belirleyicilerini analiz etmeyi amaçlamaktadır. Hanehalkının ödeme yapma isteğini ortaya çıkarmak için açık uçlu şarta bağlı değerleme yöntemi kullanılmış ve katılımcının WTP'sini etkileyen faktörleri hesaba katmak için ikili logit modeli kullanılmıştır.Çalışmadan elde edilen sonuçlar, hanehalkının gelirinin, en yüksek eğitim seviyesinin ve hanehalkı reisinin yaşının vekâleti olan aylık ortalama harcamanın, katı atık yönetiminde hane halkı için ödeme yapma istekliliğinin önemli belirleyicileri olduğunu ortaya koymuştur.Diğer değişkenler, atık yönetimi için ödeme yapma isteği ile istatistiksel olarak ve anlamlı olarak ilişkili değildir. Bu çalışmadan elde edilen bulgular, maliyet paylaşımı olasılı̆̆ı varsa katı atık yönetiminde başarı olasılı̆̆ının daha fazla olduğunu göstermektedir. 


\section{INTRODUCTION}

Over the last decade the volume of solid waste generated in large cities have been increasing at an increasing rate and this increase was largely attributed to increased urbanization due to urban migration and increasing living standards (Rathi, 2007). Increased consumption, use of disposable products and excessive packaging are creating challenges for waste management in major cities especially in developing countries. Human generate large amounts and volumes of waste and the composition of solid waste varies over time and location. Additionally the constant technological updates at household level in the form of TVs, radios, phones and other electricals entails families have a large amount of obsolete gadgets that have no formal disposal mechanisms. These gadgets contain a large number of toxic chemicals such as mercury and lead.

Efficient waste management is essential for both environmental and health of urban residents as inadequate management of solid waste poses the greatest risk to local municipality. There are many policy instruments regarding waste management, due to budgeting and infrastructural constraints most municipal authorities are often unable to manage large volumes of solid waste generated. Solid waste management system comprise waste generation, collection, transportation and disposal (Sharholy et al, 2007), thus waste management requires adequate budgetary and infrastructural provision.

There is increased concern that waste management in many cities of Zimbabwe is of poor quality and collection of garbage is irregular. This is evidenced by raw sewage flowing down streets and uncollected garbage in most residential locations. Investigations revealed that these poor waste management practices provide a range of health hazards to city residents as evidenced by increased incidences of cholera and typhoid in major Zimbabwean cities. Thus solid waste management is one of the most important environmental and health problem in major cities in the countries.

Residents in most parts of Zimbabwe adopted informal waste disposal arrangements at their own personal costs in addition to municipal rates charges. This illegal waste disposal is the major concern for human health and environmental degradation in many urban centres. Thus local municipal must improve their solid waste management. However, for this improvement a higher cost is also explored anticipated as a result it is very important to find the possibilities of cost sharing by households. Then the question will be what are residents of Gweru willing to pay to increase efficiency and improved waste collection? Previous studies have shown that household willingness to pay is usually associated with monthly income, education level, age and household size (Alta et al., 1996). However, there is limited information on the factors influencing willingness to pay for solid waste management in Zimbabwe main cities especially when the general economic. This study therefore intends to identify the factors influencing willingness to pay for solid waste management in Gweru city.

\section{LITERATURE REVIEW}

Researches that have so far been carried indicate that waste management is a common phenomenon in almost every community as emphasised by a number of empirical evidence in this study. A research by Thirumarpan,(2015) from a binomial logistic regression confirmed that household willingness to pay for improved solid waste management in Batticaloa in Sri-lanka, is significantly influenced by average household income and expenditure, household size positively. However, quantity of waste generated, number of times disposing the waste and gender had a negative and significant influence on willingness to pay for improved solid waste management.

Nkansah et al. (2015), used a cross sectional survey of a sample of 156 households in Tema Metropolis using Contigent Valuation Method in Ghana. A tobit regression was used to estimate the determinants of willingness to pay for improved solid waste management. The study concluded that income, educational level, number of dependants, house hold size influences the willingness to pay for sanitation improvements.

Naeem et al., (2013) In order to find out HH's willingness to pay for solid waste management in district Peshawar in Pakistan, Binomial logit Regression model was used. The results were derived by using statistical packages SPSS. The regression results indicate that income, education, awareness, households size and diseases history have significant impact on HH's willingness to pay. The results show that almost all the variables included in the model are significant. 
Haile, (2011) in a research titled determinants of effective household solid waste management in Ethiopia in Ambo town used a sample of 200 households and a logistic regression to identify factors that determine the effectiveness of solid waste management. The descriptive findings shows that plastic paper and ash constitute major waste bulk and that there is a positive relationship between households' income and waste management. Logistic regression analysis concluded that household head sex, household head education level, household's location that is distance from the main road, household's willingness to pay, household's access to private waste collectors services and awareness on solid waste management are the main determinants of effective solid waste management.

The study to examine the economic value of improved household solid waste management in Ibadani nNorth Local Government Oyo State, according to Salimonu and Ojo, (2007) they concluded that significant factors that determine household's willingness to pay are the price of the service, age, educational level, household size and household's monthly expenditure.

\section{METHODOLOGY}

\subsection{Data Source}

The data collection was carried out by means of questionnaires and interviews. A stratified random sampling technique was applied to collect data whereby households were selected according to location and quality of housing. A total number of 80 respondents were selected and interviewed; 56 from high income group and 26 from the other group. The respondents were asked whether they can support a new waste management strategy if it would cost them a certain amount of money each month. In addition the respondents were asked a series of socio-economic questions (education, household size, monthly average household expenditure, environment awareness, informal disposal arrangement.

\subsection{Model Specification}

Data collected from survey was analyzed using a logit model based contingent valuation method. The household WTP question was a dichotomous choice i.e. Yes / No, hence the study applied a binary logit model (Greenie, 2003). To identify the factors influencing willingness to pay for waste management by households, a binary willingness to pay was regressed against a vector of socioeconomic characteristics of households.

The probability $\mathrm{P}$ of that the respondent will be willing to pay for improved waste disposal is given by:

$$
\text { 의 } \operatorname{Pr}(W T P=1 / 0)=X_{i} \beta_{i}+\varepsilon \text {. }
$$

Where - vector of parameters to be estimated and

$\chi \quad$ - Vector of independent variables

WTP is function of monthly average household expenditure, age of household head, household size, education, environment awareness and informal disposal arrangement.

Then for willingness to pay $(=1 / 0)$ is given by:

$$
\left.\log (\operatorname{Pr}(W T P) /(1-W T P))=\beta_{0}+\beta_{1} E d u+\beta_{2} H h s+\beta_{3} E A+\beta_{4} M A E+\beta_{5} I W D A+\beta_{6} A G E+\varepsilon\right)
$$

Where,

$\mathrm{WTP}=$ willingness to pay for waste management

Edu=highest level of education for household head

Hhs=household size 
$\mathrm{EA}=$ environmental awareness

MAE=monthly average expenditure

IWDA=Informal waste disposal.

$\mathrm{AGE}=$ age of household head

, =parameters to be estimated

The mean willingness to pay MWTP is estimated as:

$M W T P=\frac{1}{\beta_{1}} \ln \left(1+e^{\beta_{0}}\right)$

Where - estimated coefficient associated with payment out

$\beta_{0}$ - Sum of estimated coefficient $\mathrm{x}$ their means. The odds of willingness to pay for improved waste management among urban households are given by:

$\beta=\log i t[(p(1)-\log i t(0)]$

$=\log [(p(1) /(1-p(1)) / p(0) /(1-p(0)]$ and the regression coefficient in the model is given

by: $e^{\beta}=e^{[p(1) / 1-p(1) / p(0) / 1-p(0)]}$

The parameters were estimated using maximum likelihood estimation.

\section{FINDINGS}

The determinants of willingness to pay for solid waste management were estimated using a binary logistic regression model and the findings of the regression are given in table 1 below.

Table 1. Logistic regression

\begin{tabular}{|l|l|l|l|l|}
\hline WTP & COEFF. & STD.ERR & $\mathbf{Z}$ & P>(Z) \\
\hline Tow & $\mathbf{0 . 2 1 2 0 6 3 4}$ & 0.7407609 & 0.29 & $\mathbf{0 . 7 7 5}$ \\
\hline Logmage & $\mathbf{1 . 7 1 0 0 5 1 ^ { * }}$ & 0.9932676 & 1.72 & $\mathbf{0 . 0 8 5}$ \\
\hline Logage & $\mathbf{4 . 6 1 3 7 0 5 *}$ & 2.650533 & 1.74 & $\mathbf{0 . 0 8 2}$ \\
\hline Loghle & $\mathbf{6 . 0 6 5 8 7 7 ^ { * * }}$ & 2.841602 & 2.13 & $\mathbf{0 . 0 3 3}$ \\
\hline ms & $\mathbf{- 0 . 3 3 3 9 8 7 8}$ & 1.086448 & -0.31 & $\mathbf{0 . 7 5 9}$ \\
\hline Cons & $\mathbf{- 1 5 . 0 0 0 5}$ & 5.793427 & -2.59 & $\mathbf{0 . 0 1 0}$ \\
\hline
\end{tabular}

$* * *, * *, *$ denotes significance at $1 \%, 5 \%$ and $10 \%$ respectively

Log likehood $=-46.530754$

LR chi2 (5) $=16.04$ Prob >chi2 $=0.0067$ Pseudo $\mathbf{R}^{\wedge} 2=-0.40720697$ 
Logistic regression results gave a pseudo R2 of about 41 percent which means at least one of the variables if different from zero as 41 percent of the variations in willingness to pay for solid waste management in the city of Gweru can be explained by the independent variables in the model. The chi-square value of 0.0067 which is significant at $1 \%$ that's confirming goodness of fit of this logistic regression model which shows that the model has explanatory power as there is no evidence of gross deficiencies with the model. The chi-square implies that one or more of the variables are important in predicting willingness to pay for improved solid waste management in Gweru city.

Table 2. Marginal effects

\begin{tabular}{|l|l|l|l|l|l|}
\hline Variable & $\mathbf{d y} / \mathbf{d x}$ & Std.err & $\mathbf{Z}$ & $\mathbf{p}>(\mathbf{z})$ & $\mathbf{X}$ \\
\hline Tow & $\mathbf{0 . 0 5 1 1 8 9 9}$ & 0.17876 & 0.29 & $\mathbf{0 . 7 7 5}$ & 1.15 \\
\hline Logmage & $\mathbf{0 . 4 1 2 7 8 8 2} *$ & 0.24005 & 1.72 & $\mathbf{0 . 0 8 6}$ & 2.06705 \\
\hline Logage & $\mathbf{0 . 1 1 3 7} *$ & 0.63858 & 1.74 & $\mathbf{0 . 0 8 1 0}$ & 1.66171 \\
\hline Loghle & $\mathbf{0 . 1 4 6 4 2 3 9 * *}$ & 0.6809 & 2.15 & $\mathbf{0 . 0 3 2}$ & 0.535714 \\
\hline ms & $\mathbf{- 0 . 0 8 0 6 2 1 1}$ & 0.26202 & -0.31 & $\mathbf{0 . 7 5 8}$ & 0.209233 \\
\hline
\end{tabular}

$* * *, * *, *$ denotes significance at $1 \%, 5 \%$ and $10 \%$ respectively

From the table 2, the marginal effects results also confirm the logistic results in Table 1, the log of highest level of education (loghle); log of monthly average expenditure (log mage) and log of age (logage) are the significant variables in the model. The likelihood of households paying a given price for improved solid waste management increases as age of respondents increases. As the age of respondents increases, the likelihood of willingness to pay for waste disposal increases. This can be explained by the fact that as people become older they tend to understand the need for a clean environment more compared to younger people. Older people tend to appreciate the importance and need for a clean and safe environment hence a positive relationship between age and willingness to pay for improved waste management.

There exists a significant and positive relationship between household monthly income as proxied by monthly average expenditure and household willingness to pay for improved waste management. A dollar increase in income increases the probability of willingness to pay by $41 \%$ as households with higher income tends to prefer a clean and safe environment hence they are more likely willing to pay for improved waste management compared to those with less income. This supports the theoretical evidence a positive relationship between household income and the demand for environmental quality improvement.

The level of education as measured by the number of years of schooling is statistically significant in influencing willingness to pay for improved solid management. As the coefficient of education is positive, an increase in education increases the probability of household willingness to pay for improved waste management. A one more year increase in education would increase the likelihood of willingness to pay by $17 \%$. This can be because education tends to enlighten households on the importance of an improvement in waste management and the risks associated with improper waste disposal.

Table 3. Odd ratios

\begin{tabular}{|l|l|l|l|l|l|}
\hline WTP & Odds ratio & Std err & Z & P>(Z) & 95\% C.I \\
\hline Logmage & $\mathbf{5 . 5 6 9 5 0 8 *}$ & 5.491684 & 1.74 & $\mathbf{0 . 0 8 2}$ & 38.47019 \\
\hline Logage & $\mathbf{9 0 . 8 0 9 7 7 *}$ & 237.2272 & 1.73 & $\mathbf{0 . 0 8 4}$ & 15197.47 \\
\hline hle & $\mathbf{4 0 8 . 6 2 7 4 *}$ & 1142.516 & 2.15 & $\mathbf{0 . 0 3 2}$ & 98010.93 \\
\hline
\end{tabular}

Source: $* * *, * * *$ denotes significance at $1 \%, 5 \%$ and $10 \%$ respectively 
The odd ration tests the hypothesis that the coefficients are equal to one and the results of the odds are shown on table 3 above. From table 3 above, the estimated odds that a household with a higher monthly average expenditure will be willing to pay for improved waste management is 5,57 times greater compared to the odds for a household with less monthly average expenditure. This signifies the importance of income in influencing the desire for household to manage and conserve the environmental quality. Older people are more likely willing to pay for improved service delivery by 91 times more compared to younger generations as older people are more conscious of the environment and service delivery. Younger generations tend to view service delivery as the sore responsibility of the government and local municipalities. Education tends to play an important role in influencing willingness to pay for improved solid waste management. The estimated odds for household highest level of education is 408.6.

\section{CONCLUSIONS and RECOMMENDATIONS}

The determinants of willingness to pay for improved waste management were identified using binary logistic regression model. The variables mean average expenditure, highest level of education of household head and age of household were noted to significantly influence household's likehood of willingness to pay for an improvement in solid waste management.

Households were generally prepared to pay a certain amount towards improved waste management as the households view waste management as a shared and collective responsibility. For the results, there is need to increase investment in education and promotion of public environmental quality awareness. This will help households to understand and appreciate the need for an improvement in environmental quality. The household with an understanding and appreciation of environmental quality will not solely depend on the government and municipal authorities for waste management as household will pledge more and be prepared to pay for environmental improvement.

\section{REFERENCES}

ALTA, A. A. \& DESHAZ, O. J. (1996). Households Demand for improved solid waste management, a case study of Gujarwala Pakistan. Word Dev., 24 (5), 857-868.

ASHENAFI, Haile, (2011). Determinants of effective Household solid waste management practices: The case of Ambo Town -West Showa Zone Mekelle University Ethiopia

\section{GREEN, W. (2003). Econometric analysis. New York University}

Krishnal Thirumarpan and MSA Dilsath , (2015).Household willingness to pay for improved solid waste management in Batticaloa, Sri Lanka. Tropical Agriculture Research and Extension 18 (2).

Mufeed Sharholy, Kafeel Ahmad, R.C. Vaishya , R.D. Gupta (2007). Municipal solid waste characteristics and management in Allahabad, India. Waste Management 27 (2007) 490-496

Naeem Ur Rehman Khattack., Suleman Amin,(2013). Willingness to pay for the treatment of environmental hazards ; Acase Study Peshawar :Asian Economic and Financial Review 3(7) : 831 - 842

Naeem Ur Rheman Khattak, Jangraiz Khan and Iftikhar Ahmad, (2013). An analysis of willingness to pay for better solid waste management services in Urban Areas of District Peshawar: MPRA PAPER No. 51184

NKANSHA, E., DAFOR. N, K, ESSEL-Gaisey, F. (2015).Willingness to pay for improved solid waste disposal in Tema Metropolis: UDS International Journal of Development Volm 2 No.9

OJOK, J., KOECH,.M.K, TOLE, M. \& OKOT, J-Okum. (2012). Household willingness to pay for improved municipal solid waste Management Services in Kampala Uganda: Science Journal of Environmental Engineering Research ISSN: 2276-7495 
Pham Thi Thuy Trang., Dinh Quang Toan and Nguyen ThiXuan Hanh,( 2017).Estimating Household Willingness to pay for Improved Solid Waste Management ; A Case Study of Thu Dau Mot City ,Binh Doung Matec Web Conference 95, 18 -004

RATHI, S. (2007). Optimization model for integrated municipal solid waste management in Mumbai, India

YUSURF, .S.A, Salimonu K.K and Ojo.O.T, (2007).Determinants of Willingness to Pay for Improved Household solid waste Management in Oyo State :Nigeria Research Journal of Applied Science 2(3) 233-239. 